\title{
Bafra Ovası Sol Sahilinde Yetiştirilen Bazı Çeltik Çeşitlerinin Verim ve Kalite Performanslarının Belirlenmesi
}

\author{
Hasan AKAY $^{1} \quad$ İsmail SEZER ${ }^{1} \quad$ Zeki MUT $^{2} \quad$ Orhan DENGİZ $^{3}$ \\ ${ }^{1}$ Ondokuz Mayıs Üniversitesi, Ziraat Fakültesi, Tarla Bitkileri Bölümü, Samsun \\ ${ }^{2}$ Bozok Üniversitesi, Ziraat Fakültesi, Tarla Bitkileri Bölümü, Yozgat \\ ${ }^{3}$ Ondokuz Mayıs Üniversitesi, Ziraat Fakültesi, Toprak Bilimi ve Bitki Besleme Bölümü, Samsun \\ $\triangle$ : hasan.akay@ omu.edu.tr
}

Geliş (Received): 04.11.2017

Kabul (Accepted): 15.12.2017

\begin{abstract}
ÖZET: Araştırma 2011-2012 yıllarında Samsun Bafra ilçesine bağlı ve Bafra Ovası üzerinde yer alan Fener köyünde 3 farklı arazi uygunluk sinıfinda (S1-uygun toprak tipi, S2-orta uygun toprak tipi ve S3- az uygun toprak tipi) ve 14 çeşidinde; olgunlaşma gün sayısı, yatma, bitki boyu, salkım uzunluğu, salkımda tane sayısı, salkım ağırlığı, bin tane ağırlığı, hasat indeksi, kırıksız randıman ve tane verimi parametreleri incelenmiştir. Tane verimi Bafra S1, S2 ve S3 çevrelerinde sırası ile $700.73,647.18$ ve 610.30 kg da-1 olarak belirlenmiştir. Kırıksız randıman Bafra S1, S2 ve S3 çevrelerinde sırası ile \% 62.99, 61.25 ve 56.72 olarak bulunmuştur. Çeltik yetiştirme alanlarında tane verimi (kg da1) bakımından değerlendirme yapıldığında, S1 arazi uygunluk sınıfında Efe, Halilbey, Osmancık97, Mis-2013; S2 arazi uygunluk sinıfinda Efe ve Halilbey ve S3 arazi uygunluk sinıfinda Mis-2013 ve Ağustos çeşitlerinin yetiştiriciliğinin yapılması tavsiye edilmektedir. Bafra ovasında yaklaşık 120.000 dekar alanda çeltik yetiştiriciliği yapılmakta olup, yaklaşık \%75 civarında Osmancık-97 çeşidi ekilmektedir. Araştırma sonucunda Efe çeşidinin tüm arazi uygunluk sınıflarında en yüksek verim vermiş olması Bafra için Osmancık-97 çeşidine Efe çeşidinin alternatif olabileceği ortaya çıkmıştır. Bafra'da arazi uygunluk sınıfında en yüksek verimi Efe çeşidi verdiği için Bafra S1 ve S2 çeltik üretim alanlarında Efe çeşidi öncelikle tavsiye edilmektedir.

Anahtar Kelimeler: Çeltik, verim, kalite, arazi uygunluk sınıfi
\end{abstract}

\section{Yield and Quality Performance of Some Paddy Cultivars Grown in Left Bank of Bafra Plain}

ABSTRACT: The study was carried out in Fener village, which is connected to the Samsun Bafra district in 20112012 and located on the Bafra Plain, (S1 - suitable soil type, S2 - medium suitable soil type and S3 - less suitable soil type) and 14 types; Ripening number of days, plant height, panicle length, kernel yield per decare, number of kernels per panicle, harvest index, unbroken kernel ratio and thousand kernel parameters were investigated. Kernel yields at Bafra S1, S2 and S3 environments were respectively measured as 700.73, 647.18 and $610.30 \mathrm{~kg} / \mathrm{da}$. Efe cultivar with the greatest kernel yield $(831.93 \mathrm{~kg} / \mathrm{da})$ was placed in the first group. The lowest kernel yield was observed in Tunca cultivar $(317.90 \mathrm{~kg} / \mathrm{da})$ and it was placed in the last group. Unbroken kernel ratios of S1, S2 and $\mathrm{S} 3$ environments were respectively observed as $62.99,61.25$ and $56.72 \%$. Considering the kernel yields (kg/da) of Bafra paddy fields, it was recommended that Efe, Halilbey, Osmancik-97 and Mis-2013 cultivars could be cultured in Bafra S1 environments, Efe and Halilbey could be cultured in Bafra S2 environments and Mis-2013 and Agusto cultivars could be cultured in Bafra S3 environments. Paddy culture is practiced over 120000 decares in Bafra plain and Osmancik cultivar is grown in almost $75 \%$ of these lands. Since Efe cultivar had the greatest yields in all environments, it was concluded that Efe cultivar could be used as an alternative to Osmancik cultivar in paddy fields of Bafra plain. Efe cultivar is recommended to be grown especially in Bafra S1 and S2 paddy culture environments. Key Words: Paddy, yield, quality, land availability class

\section{GíRiş}

Sicak iklim tahıllarından olan çeltik (Oryza sativa L.) dünya nüfusunun yaklaşık yarısının besin kaynağı olup, 2.7 milyar insanın kalori ihtiyacının \% 80'ini karşılayan en önde gelen tahıllardan bir tanesidir. Dünya nüfusunun üçte biri pirinç ile beslenmektedir. Çeltik dünyada tahıllar arasında en fazla üretilen, buğdaydan sonra ise en fazla ekim alanına sahip olan tahıl türüdür. Ülkemizde 2015 yılı itibariyle çeltiğin ekiliş alanı 115.856 ha, üretimi 920.00 ton olup, verimi $794 \mathrm{~kg} / \mathrm{da}$ dünya ortalaması üzerine olmuştur. Ülkemizin 7 coğrafi bölgesinde de çeltik bitkisi yetiştirilmektedir. Bölgelere göre en fazla ekim alanı 80.564 ha ile Trakya Bölgesinde gerçekleşirken, bu bölgemizi 28.299 ha ekim alanıyla Karadeniz Bölgesi takip etmektedir. Marmara Bölgesinde 2.803 ha, Akdeniz
Bölgesinde 1.012 ha, İç Anadolu Bölgesinde 711 ha ve diğer bölgelerde 2.356 ha çeltik ekim alanı vardır (Anon., 2016). Araştırmanın yapıldığı Bafra (Samsun) ilçesinde ekim alanı 11.079 hektar, üretim miktarı 95.584 ton ve dekara verimi ise $811 \mathrm{~kg} \mathrm{da}{ }^{-1}$ olarak gerçekleşmiştir. Türkiye üretimin \% 10 'ünü araştırma bölgesinden karşılanmaktadır (Anon., 2016). Bu nedenle bölgede en iyi performansı gösteren çeşidin kullanılması, birim alanda verim artırılarak, üretime katkı sağlanacaktır.

\section{MATERYAL ve METOT}

Araştırma 2011-2012 yıllarında Samsun Bafra ilçesine bağlı ve Bafra Ovası üzerinde yer alan Fener Köyü, 3 arazi uygunluk sinıfinda (S1-uygun toprak tipi, S2-orta uygun toprak tipi ve S3- az uygun toprak tipi) ve 14 çeşit 
kullanılarak, 3 tekerrürlü olarak, tesadüf blokları deneme desenine göre kurulmuştur.

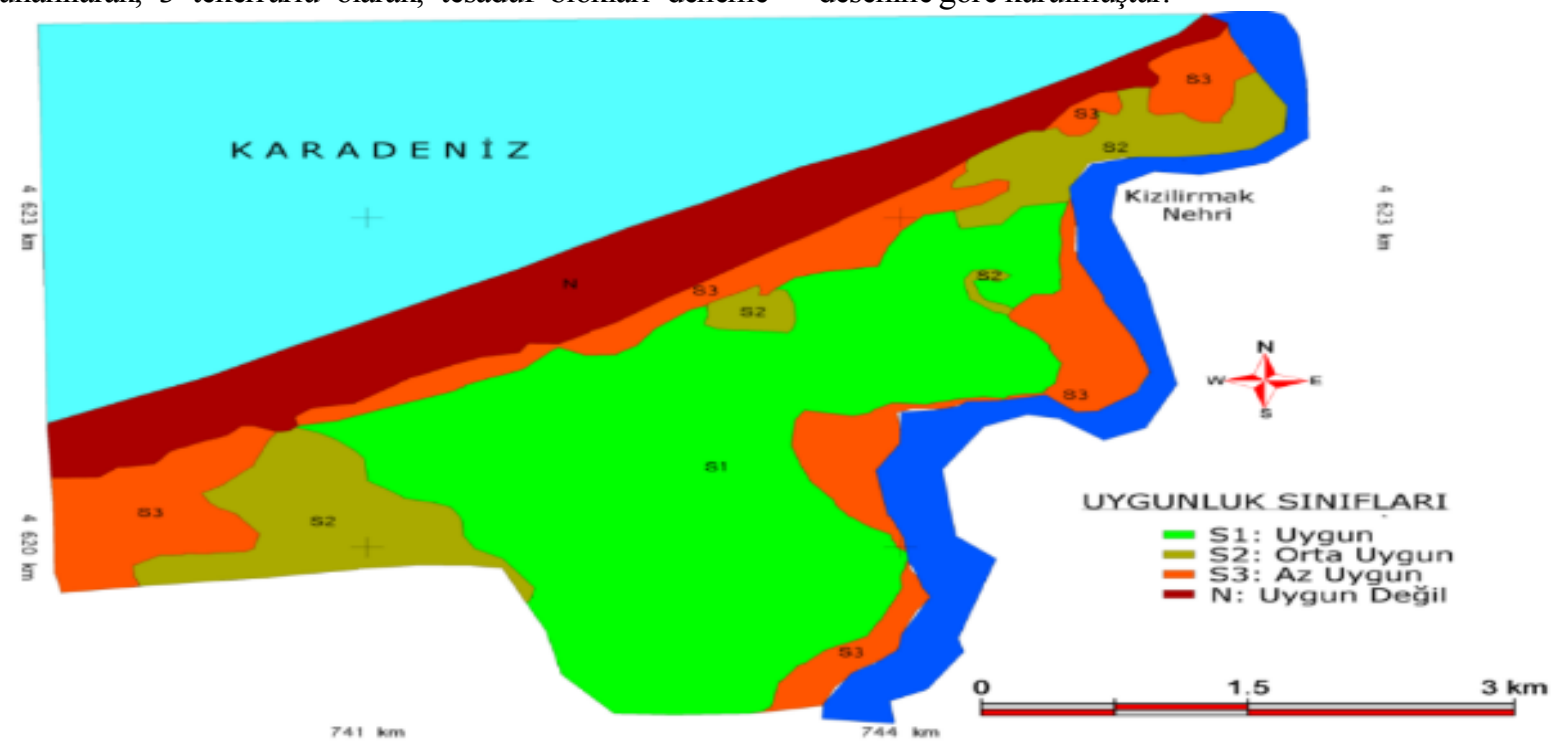

Şekil 1. Fener köyü çeltik arazi uygunluk sınıfi haritası

Araştırma, "Coğrafi Bilgi Sistem Modellemesi ile Çeltik Arazi Uygunluk Sınıflarının Belirlenmesi. Pilot Alan; Bafra Ovası Sol Sahili Fener Köyü’ isimli BAP projesi (Proje No: PYO. ZRT. 1901.12. 001) kapsamında; Samsun ili Bafra ilçesi Fener köyünde 3 farklı pilot bölgenin toprak özellikleri (fiziksel, kimyasal, morfolojik ve verimlilik) belirlenmiş, dağılım alanları haritalanması ve bu alanlara yönelik toprak veritabanları oluş̧urulmuştur. Daha sonra coğrafi bilgi sistemi ortamında toprak veri tabanı oluşturularak geliştirilen model yardımıyla, çeltik bitkisinin arazi ve toprak isteklerine göre çeltik uygunluk sınıflarına ait alanlar belirlenmiş ve haritalanmıştır (Şekil 1). Denemeler çeltik tarımına hiç uygun olmayan $(\mathrm{N})$ sinif haricinde kalan S1 (uygun), S2 (orta uygun) ve S3 (az uygun) arazi uygunluk sinıfi düzeylerinde gerçekleştirilmiştir. S1 olarak tanımlanan topraklar incelendiğinde, toprak tesktürü siltli killi tınlı, toprak profili derin, iyi drenajlı, tuzsuz, alkali olmayan yapıda olup, Azot ve çinko elementleri açısından yüksek seviyede, fosfor bakımından yeterli seviyede ve potasyum bakımından orta düzeyde olduğu tespit edilmiştir. S2 olarak tanımlanan topraklar incelendiğinde, toprak tesktürü killi tınlı, toprak profili derin, yetersiz drenajlı, orta tuzlu, hafif alkali yapıda olup, Azot, potasyum ve çinko elementleri açısından yeterli seviyede ve fosfor bakımından yetersiz olduğu tespit edilmiştir. S3 olarak tanımlanan topraklar incelendiğinde, toprak tesktürü kumlu tınlı, toprak profili sığ, iyi drenajlı, orta tuzlu, alkali yapıda olup, Azot, potasyum, fosfor ve çinko elementleri açısından yetersiz olduğu tespit edilmiştir. $\mathrm{Bu}$ çalışmada bitki materyali olarak 14 adet çeltik çeşidi (Osmanckk-97, Gala, Aramotik-1, Mis-2013, Halilbey, Paşalı, Bafra Yıldızı, Çakmak, Tunca, Efe, Hamzadere, Agusto, OMUH-1 ve OMUH-2) kullanılmıştır. Denemelerin yürütüldüğü 2012 ve 2013 yilı ile uzun y1llar (1974-2013) boyunca kaydedilen toplam yağış, ortalama nem ve ortalama sıcaklık değerleri bakıldığında araştırma alanı tipik karadeniz iklimine sahiptir. Ortalama nem bakımından araştırmanın yürütüldüğü yıllarda ortalama \% 70'in üzerinde olduğu, ortalama sicaklığı ise $15-25{ }^{0} \mathrm{C}$ arasında değiştiği ve çeltik yetiştiriciliği için elverişli olduğu görülmüştür. Araştırmada olgunlaşma gün sayısı, yatma, bitki boyu, salkım uzunluğu, dekara çeltik verimi, salkımda tane sayısı hasat indeksi, kırıksız pirinç randımanı ve bin tane ağırlığı parametreleri incelenmiştir. Serpme ekim yönteminin uygulandığı denemede parsel büyüklüğü 4 $\mathrm{x} 4=16 \mathrm{~m}^{2}$, hasat alanı ise $3 \times 4=12 \mathrm{~m}^{2}$ olacak şekilde kenar tesiri atılarak parsel verimleri alınmıştır.

\section{BULGULAR ve TARTIŞMA}

Olgunlaşma gün sayısı: Yıllar ve çevreler itibariyle olgunlaşma gün sayıları arasında farklılıklar görülmüştür. En erken olgunlaşma süresi ortalama 116.5 gün ile Hamzadere çeşidinde gerçekleşirken, en uzun olgunlaşma süresi Aromatik-1 ve Mis-2013 çeşitleriyle 127.8 gün ile gerçekleşmiştir. Olgunlaşma gün sayılarının genotiplere ve çevre şartlarına göre değiştiğini, diğer araştırmalarda da belirtilmiştir (Köycü ve ark.. 1994). S1 arazi uygunluk sınıfinda olgunlaşma gün sayısı S2 ve S3 arazi uygunluk sinıflarına göre daha fazla gerçekleşmiştir (Çizelge 1).

Yatma: Tüm çevrelerin ve çeşitlerin ortalaması 2.9 olurken. çevrelerden S1, S2 yatma değerleri ortalamanın üzerinde yer almıştır. S1 toprak sınıflarına sahip deneme alanlarında, yatma, S2 ve S3 toprak sinıflarına göre daha fazla olmuştur. Paşalı çeşidinin 4.3 değeri ile en yüksek yatma özelliğini gösterdiğini, Aromatik ve OMUH-2 çeşitlerinin de 1 değerini alarak hiç yatmadıkları görülmektedir (Çizelge 1). Bitkinin yatmasına, genetik yapısı, bitkinin kök sistemi, bitki boyu, sapın sağlamlı̆̆ı ve elastikliği sebep olabilir. 
Çizelge 1. 2012-2013 yıllarının ortalamasına ait olgunlaşma gün sayısı ve yatma değerleri

\begin{tabular}{l|ccc|c|ccc|c}
\hline & \multicolumn{3}{|c|}{ Olgunlaşma gün sayısı (gün) } & \multicolumn{4}{c}{ Yatma } \\
Ç. & S1 & S2 & S3 & Ort. & S1 & S2 & S3 & Ort. \\
\hline $\mathbf{1}$ & 128.0 & 125.0 & 120.5 & $\mathbf{1 2 4 . 5}$ & 4.0 & 4.0 & 1.0 & $\mathbf{3 . 0}$ \\
$\mathbf{2}$ & 125.5 & 123.5 & 121.5 & $\mathbf{1 2 3 . 5}$ & 4.0 & 4.0 & 1.0 & $\mathbf{3 . 0}$ \\
$\mathbf{3}$ & 131.5 & 128.0 & 125.0 & $\mathbf{1 2 7 . 8}$ & 1.0 & 1.0 & 1.0 & $\mathbf{1 . 0}$ \\
$\mathbf{4}$ & 130.0 & 128.0 & 125.5 & $\mathbf{1 2 7 . 8}$ & 3.0 & 3.0 & 3.0 & $\mathbf{3 . 0}$ \\
$\mathbf{5}$ & 120.0 & 118.0 & 116.0 & $\mathbf{1 1 8 . 0}$ & 5.0 & 5.0 & 3.0 & $\mathbf{4 . 3}$ \\
$\mathbf{6}$ & 119.0 & 117.5 & 115.0 & $\mathbf{1 1 7 . 2}$ & 4.0 & 4.0 & 1.0 & $\mathbf{3 . 0}$ \\
$\mathbf{7}$ & 121.5 & 119.0 & 117.5 & $\mathbf{1 1 9 . 3}$ & 3.0 & 3.0 & 1.0 & $\mathbf{2 . 3}$ \\
$\mathbf{8}$ & 130.0 & 127.0 & 126.0 & $\mathbf{1 2 7 . 7}$ & 6.0 & 5.0 & 1.0 & $\mathbf{4 . 0}$ \\
$\mathbf{9}$ & 131.0 & 127.0 & 127.0 & $\mathbf{1 2 8 . 3}$ & 6.0 & 5.0 & 2.0 & $\mathbf{4 . 3}$ \\
$\mathbf{1 0}$ & 123.5 & 119.0 & 119.5 & $\mathbf{1 2 0 . 7}$ & 3.0 & 2.0 & 1.0 & $\mathbf{2 . 0}$ \\
$\mathbf{1 1}$ & 118.0 & 116.5 & 115.0 & $\mathbf{1 1 6 . 5}$ & 5.0 & 4.0 & 2.0 & $\mathbf{3 . 7}$ \\
$\mathbf{1 2}$ & 129.0 & 126.5 & 126.0 & $\mathbf{1 2 7 . 2}$ & 3.0 & 4.0 & 2.0 & $\mathbf{3 . 0}$ \\
$\mathbf{1 3}$ & 129.0 & 126.0 & 127.0 & $\mathbf{1 2 7 . 3}$ & 4.0 & 4.0 & 2.0 & $\mathbf{3 . 3}$ \\
$\mathbf{1 4}$ & 129.0 & 126.0 & 127.0 & $\mathbf{1 2 7 . 3}$ & 1.0 & 1.0 & 1.0 & $\mathbf{1 . 0}$ \\
\hline
\end{tabular}

Bitki Boyu: Bitki Boyu bakımından denemelerin genel ortalaması olarak $94.60 \mathrm{~cm}$ bulunmuştur. Bitki boyu, S1, S2, S3 çevrelerinde sırası ile 94.91, 94.43, $94.47 \mathrm{~cm}$ olarak bulunmuştur. İstatistiki olarak değerlendirildiği zaman bitki boyu yönünden S1 çevresi ilk gurupta (a) yer alırken, S2 ve S3ikinci gurupta (b) yer almıştır. Çeşitlerin ortalaması olarak en uzun bitki boyu $(101.01 \mathrm{~cm})$ Bafra Yıldızı çeşidinden iken en düşük ise OMUH-2 çeşidinden (71.66 $\mathrm{cm}$ ) elde edilmiştir (Çizelge 2). Çeltik çeşitleri ile daha önce yapılan çalışmalarda bitki boyunu 76-165 cm (Şavşatlı ve ark. 2006), 79.7-109.7 cm (Sezer ve Köycü 1999), 85-120 cm (Düzgün ve ark. 1990), 98.9-127.8 cm (Köycü ve ark. 1994)arasında kaydetmişlerdir. Önceki araştırıcıların yapmış oldukları çalışmalardanda anlaşıldığı gibi çeltikte bitki boyunun çeşide yıllara, çevreye ve uygulanan faktörlere göre değiștir. $\mathrm{Bu}$ bulgular bizim çalışmamaızda da gözlenmiştir.

Salkım Uzunluğu: Salkım uzunluğu bakımından denemelerin genel ortalaması olarak $13.61 \mathrm{~cm}$ bulunmuştur. Salkım uzunluğu Bafra $\mathrm{S} 1$, S2 ve S3 çevrelerinde sirası ile $13.10,13.20$ ve $14.52 \mathrm{~cm}$ olarak belirlenmiștir. İstatistiki olarak değerlendirildiği zaman S3 çevresi ilk gurupta (a) yer alırken, S1 ve S2 çevreleri ikinci gurupta (b) yer almışlardır. Aromatik-1 ve Agusto çeşitleri en yüksek salkım uzunluğu $16.14 \mathrm{~cm}$ ve $15.77 \mathrm{~cm}$ ile ilk grupta iken en düşük ise Çakmak, Hamzadere ve Gala çeşitlerinden $(12.05,12.06$ ve12.07 cm) elde edilmiş olup bu çeşit son grupta (f) yer almıştır (Çizelge 2). Araştırmada elde edilen sonuçları diğer araştırıcıların sonuçlarıyla karşılaştırdığımızda bulduğumuz salkım uzunluğu değerlerinin, salkım uzunluğunu $13-19 \mathrm{~cm}$ Düzgün ve ark. (1990), 15.1-18 cm Şahin ve ark.(2011), 14.8-19.3 cm Sezer ve Köycü (1999), 8.80-13.50 cm İdikut (2009), 18.10-22.06 cm İdikut ve ark. (2010) ile uyum göstermektedir.

Salkımda Tane Sayısi: Salkımda tane sayıs1 bakımından denemelerin genel ortalaması olarak 102.62 adet bulunmuştur. Salkımda tane sayısı Bafra $S 1, \mathrm{~S} 2$ ve S3 çevrelerinde sırası ile $104.55,99.71$ ve 103.59 adet olarak belirlenmiştir. İstatistiki olarak değerlendirildiği zaman Bafra S1 çevresi 104.55 adet ilk gurupta (a) yer alırken, Bafra S2 çevresi 99.71 adet ile son grupta (c) yer almıştır. Mis-2013 çeşidinden en yükssek salkımda tane sayısı (135.17 adet) elde edilmiştir. En düşük salkımda tane sayısı ise (70.58 adet) ile Tunca çeşidinden elde edilmiştir (Çizelge 2). Araştırmada elde edilen sonuçları diğer araştırıcıların sonuçlarıyla karşılaştırdığımızda bulduğumuz salkımda tane sayısını 53-108.4 adet arasında bulan Köycü ve ark. (1994) 81.7-109.3 adet arasında bulan, Sezer ve Köycü (1999) 48-75 adet, İdikut (2009) 67.7097.53 adet arasında ve İdikut ve ark. (2010) 81.42-165.21 adet paralelik göstermektedir.

Salkım ağırlığı: Salkım ağırlı̆ğ bakımından denemelerin genel ortalaması olarak $3.32 \mathrm{~g}$ bulunmuştur. Salkım ağırlığ $\mathrm{S} 1, \mathrm{~S} 2$ ve S3 çevrelerinde sırası ile 3.44, 3.29 ve $3.24 \mathrm{~g}$ olarak belirlenmiştir. İstatistiki olarak değerlendirildiği zaman S1 çevresi 3.44 g ilk gurupta(a) yer alırken, S3 çevresi 3.24 g ile (c) gurubunda yer almıştır. Mis-2013 çeşidinden en yüksek salkım ağırlığı (4.38 g) elde edilmiştir. En düşük salkım ağırlığı ise $(2.39 \mathrm{~g})$ ile OMUH-1 çeşidinden elde edilmiştir (Çizelge 3). Araştırmada elde edilen sonuçları diğer araştırıcıların sonuçlarıyla karşılaştırdığımızda bulduğumuz salkım ağırlığı değerlerinin, salkım ağırlığını 2.16-4.01 g Köycü ve ark.(1994), 2.65-3.47 g Sezer ve Köycü (1999), 2.31$3.34 \mathrm{~g}$ İdikut ve ark. (2010), 2.8-3.86 g Şavşatlı ve ark (2006)'ın buldukları salkım ağırlığı değerleriyle paralellik göstermektedir.

Hasat Indeksi: Hasat indeksi bakımından denemelerin genel ortalaması olarak \% 44.43 bulunmuştur. Hasat indeksi S1, S2 ve S3 çevrelerinde sırası ile \% 45.98, 44.55 ve 43.41 olarak belirlenmiştir. İstatistiki olarak değerlendirildiği zaman hasat indeksi S1 çevresi ilk gurupta (a) yer alırken, S3 çevresi son gurupta (c) yer almıştır. Osmancık-97 çeşidinden en yüksek hasat indeksi (\% 54.11) elde edilirken, en düşük hasat indeksi ise $(\%$ 33.21) ile Tunca çeşidinden elde edilmiştir (Çizelge 3). Araştırmada elde edilen sonuçları diğer araştırıcıların 
sonuçlarıyla karşılaştırdığımızda bulduğumuz hasat indeksi değerlerinin, hasat indeksini 37.1-48.2 Sürek ve

ark.(2007)'nın buldukları değerler ile paralellik göstermektedir.

Çizelge 2. 2012-2013 yıllarının ortalamasına ait bitki boyu, salkım uzunluğu ve salkımda tane sayısı değerleri

\begin{tabular}{|c|c|c|c|c|c|c|c|c|c|c|c|c|}
\hline \multirow{2}{*}{ Ç. } & \multicolumn{4}{|c|}{ Bitki boyu (cm) } & \multicolumn{4}{|c|}{ Salkım uzunluğu (cm) } & \multicolumn{4}{|c|}{ Salkımda tane sayısı (adet) } \\
\hline & S1 & $\mathbf{S 2}$ & S3 & Ort. & S1 & S2 & S3 & Ort. & S1 & S2 & S3 & Ort. \\
\hline $\mathbf{1}$ & $\overline{07.26}$ & 102.73 & .02 & $.33 \mathrm{bc}$ & 3.94 & & 3.36 & & 12.41 & 99. & & \\
\hline 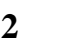 & & 00.02 & & & & & & & & & & \\
\hline 3 & & & & & & & & & & & & \\
\hline 4 & & 93.37 & 7 & & & 12 & 1 & & 75 & 12 & & נכ \\
\hline$\sqrt{5}$ & & & & & & & & & & & & \\
\hline 6 & & & 5 & & & & 1 & & & & & \\
\hline & & & & & & & 4 & & & 119.51 & & \\
\hline & & 92 & & & & & 3 & & & & & U \\
\hline & & 86.09 & 0.00 & & & & 15.72 & & & 67 & & 70.58 \\
\hline & & 95.51 & 4.63 & & & 13 & 12.44 & & 0 & 102 & & r \\
\hline 11 & & 97.24 & & & & 10 & 14 & & & 99.09 & & 9 \\
\hline & & 0.39 & & & & & & & & 113.97 & & 120.00 \\
\hline & & & & & & & & & & & & 77.91 \\
\hline 14 & 80.36 & 69.03 & 65.59 & $71.66 \mathbf{~ l}$ & 12.82 & 15.69 & 16.78 & $15.09 \mathbf{b}$ & 88.87 & 76.32 & 94.43 & 86.54 \\
\hline
\end{tabular}

\begin{tabular}{l|l|l|l|l|l|l|l|l}
\hline Ort. & 94.91 a94.43 b 94.47 & b & $\mathbf{9 4 . 6 0}$ & 13.10 b 13.20 b14.52 a & 13.61 & 104.55 a 99.71 c 103.59 b & 102.62
\end{tabular}

C: Ceșitler; 1: Osmancık-97; 2: Gala; 3:Aramotik-1; 4:Mis-2013 5:Pașalı; 6:Halilbey 7:Bafra Yıldızı 8:Çakmak 9:Tunca 10:Efe 11:Hamzadere 12:Agusto13: OMUH-1 14:OMUH-2

Çizelge 3. 2012-2013 yıllarının ortalamasına ait salkım ağırlığı, hasat indeksi ve tane verimi değerleri

\begin{tabular}{|c|c|c|c|c|c|c|c|c|c|c|c|c|}
\hline \multirow{2}{*}{ Ç. } & \multicolumn{4}{|c|}{ Salkım ağırlığı (g) } & \multicolumn{4}{|c|}{ Hasat indeksi (\%) } & \multicolumn{4}{|c|}{ Tane verimi $\left(\mathrm{kg} \mathrm{da}^{-1}\right)$} \\
\hline & S1 & $\mathbf{S 2}$ & S3 & Ort & S1 & $\mathbf{S 2}$ & S3 & Ort & S1 & $\mathbf{S 2}$ & S3 & Ort \\
\hline 1 & 3.88 & 3.48 & 3.42 & $3.59 \mathrm{e}$ & 55.53 & 54.47 & 52.34 & $54.11 \mathbf{a}$ & $852.54 \mathbf{b}$ & $677.95 \mathbf{g}$ & $625.29 \mathrm{~d}$ & $18.59 \mathrm{~d}$ \\
\hline 2 & 4.11 & 4.01 & 3.97 & $3 \mathbf{b}$ & .42 & & 49.30 & & $1.44 \mathrm{~d}$ & $7 \mathbf{e}$ & $9.93 \mathbf{b c}$ & \\
\hline 3 & 2.59 & 2.81 & 3.11 & $3 \mathbf{g}$ & 25.73 & 36.11 & 39.24 & $33.69 \mathbf{k}$ & $518.50 \mathbf{h}$ & $544.53 \mathbf{k}$ & $571.46 \mathbf{e}$ & $4.83 \mathbf{f}$ \\
\hline 4 & 4.55 & 4.13 & 4.47 & & 40.46 & & 34 & & & de & $3 \mathbf{a}$ & \\
\hline 5 & 3.14 & 3.12 & 3.03 & $9 \mathbf{f}$ & 50.75 & 44.06 & 40.09 & $7 \mathbf{e}$ & $800.36 \mathrm{c}$ & $4 \mathrm{c}$ & $710.03 \mathbf{b}$ & $4 \mathrm{c}$ \\
\hline 6 & 3.97 & 3.91 & 3.50 & $79 \mathrm{c}$ & 5216 & 52 & 43.92 & $49.42 \mathrm{c}$ & $852.21 \mathrm{~b}$ & 80 & 693.06 bc & $6 \mathrm{~b}$ \\
\hline 7 & 4.01 & 3.86 & 3.46 & $8 \mathrm{c}$ & 45.55 & 47 & 36.34 & $42.98 \mathbf{f}$ & $559.91 g$ & 55 & $442.65 \mathbf{f}$ & $4 \mathrm{~g}$ \\
\hline 8 & 2.91 & 2.42 & 2.30 & $54 \mathbf{k}$ & 50.46 & 48 & 43.38 & $47.41 \mathrm{e}$ & 597 & 51 & $443.83 \mathbf{f}$ & $4 \mathrm{~g}$ \\
\hline 9 & 2.59 & 2.44 & 2.21 & $41 \mathrm{l}$ & 32.09 & 31 & 36.25 & $33.21 \mathrm{k}$ & $285.66 \mathbf{k}$ & $2 \mathbf{m}$ & $349.53 \mathbf{g}$ & \\
\hline 10 & 3.91 & 3.82 & 3.39 & $70 \mathrm{~d}$ & 51.95 & 49.76 & 43.77 & $48.49 \mathbf{d}$ & $963.24 \mathbf{a}$ & $8 \mathbf{a}$ & $683.37 \mathrm{c}$ & $3 \mathbf{a}$ \\
\hline 11 & 3.93 & 3.79 & 3.60 & $3.77 \mathrm{c}$ & 50.35 & 47.38 & 44.26 & $47.33 \mathbf{e}$ & $757.47 \mathbf{d}$ & $2 \mathbf{d}$ & $678.59 \mathrm{c}$ & 727 \\
\hline 12 & 3.45 & 3.42 & 3.82 & $56 \mathrm{e}$ & 52.24 & 48.60 & 51.09 & 50.64 bc & $730.84 \mathbf{d}$ & $704.41 \mathbf{f}$ & $735.92 \mathbf{a}$ & $723.72 \mathbf{d}$ \\
\hline 13 & 2.38 & 2.50 & 2.31 & $2.39 \mathrm{I}$ & 45.10 & 43.28 & 41.96 & $43.45 \mathbf{f}$ & $641.38 \mathrm{e}$ & $651.32 \mathbf{h}$ & $609.30 \mathrm{~d}$ & $634.00 \mathrm{e}$ \\
\hline 14 & 2.84 & 2.35 & 2.76 & $2.65 \mathrm{~h}$ & 39.97 & 37.54 & 41.96 & $39.82 \mathbf{g}$ & 622.09 ef & 478.261 & $551.13 \mathrm{e}$ & $550.49 \mathbf{f}$ \\
\hline$\overline{\mathbf{O r}}$ & 44 & $29 \mathrm{~b}$ & $.24 \mathrm{c}$ & 3.32 & 509 & 155 & 277 & 44.43 & $700.73 \mathrm{a}$ & $647.18 \mathrm{~b}$ & $610.30 \mathrm{c}$ & 652.74 \\
\hline
\end{tabular}

Ç: Çeşitler; 1: Osmancık-97; 2: Gala; 3:Aramotik-1; 4:Mis-2013 5:Paşalı; 6:Halilbey 7:Bafra Yıldızı 8:Çakmak 9:Tunca 10:Efe 11:Hamzadere 12:Agusto13: OMUH-1 14:OMUH-2

Tane Verimi: Tane verimi S1, S2 ve S3 çevrelerinde sirası ile $700.73,647.18$ ve $610.30 \mathrm{~kg} \mathrm{da}^{-1}$ olarak belirlenmiştir. İstatistikî olarak değerlendirildiği zaman S1 çevresi ilk gurupta (a) yer alırken, S3 son gurupta (c) yer almışlardır. Efe çeşidi en yüksek tane verimi $831.93 \mathrm{~kg} \mathrm{da}^{-1}$ ile ilk grupta yer alırken, en düşük tane verimi ise Tunca çeşidinden $\left(317.90 \mathrm{~kg} \mathrm{da}^{-1}\right)$ elde edilmiş olup bu çeşit son grupta (h) yer almıştır. S1 arazi uygunluk sınıfinda elde edilen tane verimi 285.66 - $963.24 \mathrm{~kg} \mathrm{da}^{-1}$ arasinda değişiklik göstermiştir. En düşük verim $\mathrm{k}$ grubuna giren Tunca çeşidinden elde edilirken en yüksek verim a grubuna giren Efe çeşidinden elde edilmiştir. S1 arazi uygunluk çevresinde Efe çeşidinden sonra Halilbey, Osmancık-97 ve Mis-2013 çeşitleri tavsiye edilmektedir. Bafra S2 arazi uygunluk sinıfinda elde edilen tane verimi 318.52 - $849.18 \mathrm{~kg} \mathrm{da}^{-1}$ arasında değişiklik göstermiştir. En düşük verim (m) gurubuna giren Tunca çeşidinden elde edilirken en yüksek verim (a) gurubuna giren Efe çeşidinden elde edilmiştir. S2 arazi uygunluk sinıfinda en yüksek verim Efe çeşidinden $\left(849.18 \mathrm{~kg} \mathrm{da}^{-1}\right)$ elde edilmiştir. Ardından Halilbey (809.01 kg da-1) çeşidi ile ikinci verimlilik gurubuna girmişler. $\mathrm{Bu}$ yüzden Bafra $\mathrm{S} 2$ arazi uygunluk çevresinde Efe ve Halibey çeşitleri tavsiye edilmektedir. S3 arazi uygunluk sinıfinda elde edilen tane

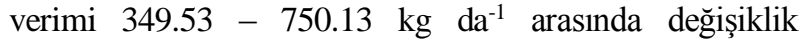
göstermiştir. En düşük verim $\mathrm{g}$ gurubuna giren Tunca çeşidinden elde edilirken en yüksek verim a gurubuna giren Mis-2013 çeşidi ve aynı gruba giren Agusto çeşidinden elde edilmiştir (Çizelge 3). Araştırmada elde edilen tane verimi değerlerini, diğer araştırıcıların sonuçlarıyla karşılaştırdığımızda, tane verimini 968.4$622.5 \mathrm{~kg} \mathrm{da}^{-1}$ Sezer ve Köycü (1999), 766.0- $658.5 \mathrm{~kg} / \mathrm{da}$ 
Şavşatlı ve Gülümser (2006), 273.22-570.53 kg da-1 İdikut (2009), 625.6 - $789.6 \mathrm{~kg} \mathrm{da}^{-1}$ Köycü ve ark. (1994)'nın açıkladığı değerlere paralellik gösterdiği görülmüştür.

Bin Tane A Ăırlığı: Bin tane ağırlı̆̆ı bakımından denemelerin genel ortalaması olarak $32.94 \mathrm{~g}$ bulunmuştur. Çeltik çeşitlerinin bin tane ağırlığı ise. $23.54 \mathrm{~g}$ (Aromatik1) ile $38.20 \mathrm{~g}$ (Hamzadere) arasında değişiklik göstermiştir. Bin tane ağırlı̆̆ Bafra S1, S2 ve S3 çevrelerinde sirası ile $33.39,33.51$ ve 31.91 gr olarak belirlenmiştir. İstatistiki olarak değerlendirildiği zaman S2 ilk gurupta (a) yer alırken, S3 çevresi son gurupta (c) yer almıştır (Çizelge 4). Araştırmada elde edilen sonuçları diğer araştırıcıların sonuçlarıyla karşılaştırdığımızda, 32.2-38 g Şahin ve ark (2011), 30-34 g Düzgün ve ark (1999), 27.19-39.7 g Şavşatlı ve Gülümser (2006), 24.81-27.90 g İdikut ve ark.
(2010), 28.74-37.63 g İdikut (2009) ile uyum göstermektedir.

Kırıksı randıman: Kırıksız randıman bakımından denemelerin genel ortalaması olarak \% 60.32 bulunmuştur. Kırıksız randıman S1, S2 ve S3 çevrelerinde sırası ile \% $62.99,61.25$ ve 56.72 olarak bulunmuştur. İstatistiki olarak değerlendirildiği kırıksız tane randımanı yönünden S1 çevresi ilk grupta (a) yer alırken, S3 çevresi son grupta (c) yer almıştır. Gala çeşidinden en yüksek kırıksız randıman (\% 66.04) elde edilirken, en düşük kırıksız randıman ise Aromatik-1 ve Çakmak (\% 52.71 ve 52.52) ile çeşitlerinden elde edilmiştir (Çizelge 4). Araştırmada elde edilen sonuçları diğer araştırıcıların sonuçlarıyla karşılaştırdığımızda \% 49.2-61.9 Sürek ve ark. (2007) ile uyum göstermektedir.

Çizelge 4. 2012-2013 yıllarının ortalamasına ait bin tane ağırlığı ve kırıksız randıman değerleri

\begin{tabular}{|c|c|c|c|c|c|c|c|c|}
\hline \multirow[b]{2}{*}{ Ç. } & \multicolumn{4}{|c|}{ Bin tane ağırlıklarına (g) } & \multicolumn{4}{|c|}{ Kırıksız randımanına (\%) } \\
\hline & S1 & S2 & S3 & Ort. & S1 & S2 & S3 & Ort. \\
\hline 1 & 34.88 & 35.38 & 32.50 & $34.25 \mathrm{~d}$ & 66.48 & 66.73 & 63.21 & $65.47 \mathrm{~b}$ \\
\hline 2 & 33.57 & 34.27 & 34.00 & $33.95 \mathbf{e}$ & 68.26 & 66.94 & 62.91 & $66.04 \mathbf{a}$ \\
\hline 3 & 24.22 & 23.39 & 23.02 & 23.541 & 55.68 & 53.92 & 48.53 & 52.711 \\
\hline 4 & 33.58 & 32.88 & 31.76 & $32.74 \mathbf{f}$ & 56.99 & 63.12 & 54.51 & $58.20 \mathrm{~g}$ \\
\hline 5 & 39.36 & 36.21 & 34.51 & $36.69 \mathbf{b}$ & 62.62 & 63.87 & 55.78 & $60.76 \mathbf{e}$ \\
\hline 6 & 34.91 & 34.88 & 33.17 & $34.32 \mathbf{d}$ & 68.77 & 63.38 & 61.68 & $64.61 \mathrm{c}$ \\
\hline 7 & 30.74 & 32.61 & 30.50 & $31.28 \mathrm{~g}$ & 58.45 & 58.68 & 57.99 & $58.37 \mathrm{~g}$ \\
\hline 8 & 32.77 & 33.79 & 31.79 & $32.78 \mathbf{f}$ & 58.66 & 52.32 & 46.57 & $52.52 \mathrm{l}$ \\
\hline 9 & 32.60 & 36.52 & 34.71 & $34.61 \mathrm{c}$ & 60.44 & 56.47 & 54.96 & $57.29 \mathrm{~h}$ \\
\hline 10 & 36.56 & 37.63 & 35.67 & $36.62 \mathbf{b}$ & 69.01 & 60.63 & 60.24 & $63.29 \mathrm{~d}$ \\
\hline 11 & 37.69 & 38.56 & 38.36 & $38.20 \mathbf{a}$ & 64.69 & 60,85 & 55.55 & $60.36 \mathbf{f}$ \\
\hline 12 & 31.43 & 30.35 & 28.48 & $30.08 \mathbf{k}$ & 61.28 & 63.03 & 6573 & $63.34 \mathbf{d}$ \\
\hline 13 & 32.85 & 31.68 & 28.83 & $31.12 \mathbf{g h}$ & 67.27 & 66.03 & 62.19 & $65.16 \mathbf{b}$ \\
\hline 14 & 32.29 & 31.03 & 29.53 & $30.95 \mathbf{h}$ & 63.31 & 61.59 & 44.26 & $56.38 \mathbf{k}$ \\
\hline Ort. & 33.39 b & $33.51 \mathrm{a}$ & $31.91 \mathrm{c}$ & 32.94 & $62.99 a$ & $61.25 \mathrm{~b}$ & $56.72 \mathrm{c}$ & 60.32 \\
\hline
\end{tabular}

Ç: Çeşitler; 1: Osmancık-97; 2: Gala; 3:Aramotik-1; 4:Mis-2013 5:Paşalı; 6:Halilbey 7:Bafra Yıldııı 8:Çakmak 9:Tunca 10:Efe 11:Hamzadere 12:Agusto13: OMUH-1 14:OMUH-2

\section{SONUÇ}

Bafra ovasında yaklaşık 120.000 dekar alanda çeltik yetiştiriciliği yapılmakta olup, yaklaşık \% 75 civarında Osmancık-97 çeşidi ekilmektedir. Araştırma sonucunda Efe çeşidinin tüm arazi uygunluk sınıflarında en yüksek verim vermiş olması Bafra için Osmancık-97 çeşidine Efe çeşidinin alternatif olabileceği ortaya çıkmıştır. Bafra çeltik yetiştirme alanlarında tane verimi bakımından değerlendirme yapıldığında; S1 arazi uygunluk sınıfinda Efe, Halilbey, Osmancik-97, Mis-2013; S2 arazi uygunluk sınıfinda Efe ve Halilbey; S3 arazi uygunluk sınıfinda Mis2013 ve Ağusto çeşitlerinin yetiştiriciliğinin yapılması tavsiye edilmektedir.

\section{TEŞEKKÜR}

Araştırma, "Coğrafi Bilgi Sistem Modellemesi ile Çeltik Arazi Uygunluk Sınıflarının Belirlenmesi. Pilot Alan; Bafra Ovası Sol Sahili Fener Köyü” isimli PYO. ZRT. 1901.12.001 no'lu BAP projesi kapsamında yürütülmüştür.

\section{KAYNAKLAR}

Anonim

2016. http://www.tuik.gov.tr/VeriBilgi.do?tb_id=45\&ust_i $\mathrm{d}=13$ (Erişim tarihi:15.10.2016).

Düzgün M, Negiş M, Konuk K 1990. Çeltikte Çeşit Belirleme. Çukurova Tarımsal Araştırma Enstitüsü, Müdürlüğü Yayın No: 10:32.

İdikut L 2009. Bazı Çeltik Genotiplerinin Kahramanmaraş Koşullarında Verim ve Verim Unsurlarının Araştırılması. Kahramanmaraş Sütçü İmam Üniversitesi Doğa Bilimleri Dergisi, 12(1):62$65 \mathrm{~s}$.

İdikut L, Akkaya A, Dokuyucu T, Bozok H 2010. Agronomic Characters of Landrace Yellowrice (Oryza sativa L.) Selected According to Plant Height and Panicle Properties. Pakistan Journal Botany 42(5):3165-3171s.

Köycü C, Sezer İ, Toksal A 1994. Çarşamba Ovasında Bazı Çeltik (Oryza sativa 1.) Çeşitlerinin Bitkisel Özellikleri ve Tane Verimi Üzerinde Bir Araştırma. OMÜ Ziraat Fakülte Dergisi, 9, (1):1-11s. 
Sezer İ, Köycü, C 1999. Kizılırmak Vadisinde Yetiştirilebilecek Çeltik Çeşit ve Hatlarının (Oryza sativa L.) Belirlenmesi üzerine Bir Araştırma. Türkiye III. Tarla Bitkileri Kongresi Kitabı, 15-20 Kasım, Adana.

Sürek H, Beşer N, Kaya R, Yatkın O, Kuşku H 2007. Son Yirmi Yılda Ülkemizde Çeltik Üretiminde Elde Edilen Genetik İlerlemenin Tesbiti. Sonuç Raporu Proje No: TAGEM/TA/04/03/06/001. Trakya Tarımsal Araştırma Enstitüsü.
Şahin M, Sürek H, Öner F, Üre T 2011. Çeltikte Çeşit ya da Çeşit Adaylarının Performanslarının Belirlenmesi ve Stabilite Analizleri. IX. Tarla Bitkileri Kongresi, 12-15 Eylül Bursa, (1) 370-375s. Şavşatlı Y, Gülümser A 2006. Fideleme ve Serpme Ekim Yöntemlerinin Bazı Çeltik Çeşitlerinde Verim ve Kalite Karakterlerine Etkileri. OMÜ Zir. Fak. Dergisi, 21(2):154-159s. 